\section{Determinants of Dividends in the Telecommunications Sector}

\author{
Maria Elisabete Duarte Neves ${ }^{1,2}$ \\ ${ }^{1}$ University of Trás-os-Montes and Alto Douro- \\ UTAD/CETRAD, Vila Real, Portugal \\ Maria Manuela Cunha ${ }^{2}$ \\ Joáo Vilas ${ }^{2}$ \\ ${ }^{2}$ Polytechnic Institute of Coimbra - Coimbra Business \\ School-ISCAC, Coimbra, Portugal
}

Recebimento:

02/18/2019

Aprovação:

$01 / 21 / 2020$

Editor responsável:

Prof. Dr. Javier Montoya Del

Corte

Avaliado pelo sistema:

Double Blind Review

\begin{abstract}
Purpose - Telecommunications stocks are known to be defensive stocks, which are less susceptible to volatility in the global financial markets and usually pay higher dividends than in other industries. In this context, this paper intends to study the influence of some specific characteristics of these companies on the payment of dividends.
\end{abstract}

Design/methodology/approach - To achieve the proposed objective, the panel data methodology was used, specifically the GMM estimation method for a sample consisting of 34 companies listed in Western Europe and North America in the period between 2007 and 2016 and in the sub-period between 2008 and 2013, which comprises the global financial crisis.

Findings - The results show that specific factors such as investment in fixed capital, indebtedness, price to book value ratio, free cash flow (FCF), liquidity, and dividends paid in the previous year are decisive in explaining the dividends distributed in the entire period. For the financial crisis period, the sign and significance of the variables remain almost unchanged, suggesting that these companies pay dividends regardless of economic cycles, covering the absence of FCF with adequate liquidity levels to satisfy investors during recessive periods.

Originality/value - Our study contributes to a better understanding of the telecommunications sector and the dividend policy carried out by managers in this sector, and it can assist in the analyses of investors, other managers, financial analysts, and researchers on the subject.

Keywords - Dividends, Telecommunications Stocks, Firms' Specific Characteristics

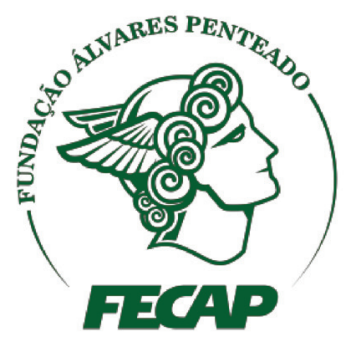

Revista Brasileira de Gestáo de Negócios

DOI: $10.7819 /$ rbgn.v22i3.4069 


\section{Introduction}

Dividend policy has long been a question of interest in the financial literature and, although there is a great deal of research on the subject, it remains an open issue.

In fact, dividends have been considered for decades as a puzzle and, since Miller and Modigliani (1961), many authors have tried to give alternative explanations for dividend policies in imperfect markets.

For example, Banerjee, Gatchev, and Spindt (2007) argue that clientele effects based on transaction costs represent a significant part of the decline in the propensity to pay dividends. Amihud and Li (2006) also document the phenomenon called "disappearing dividends" by Fama and French (2001), which describes the decrease in dividend information content since the mid-1970s, making companies less willing to incur the associated costs. DeAngelo, DeAngelo, and Skinner (2004) base their explanation of the phenomenon of declining dividends on the concentration of dividends by the main payers of North American companies, as well as on the decline in the frequency of payments of special dividends in the last few years. Brav, Graham, Harvey, and Michaely (2005) showed empirically that the greater flexibility of share buybacks has led managers to favor dividends, a result also corroborated by Skinner (2008).

In fact, the investigations have had some success in explaining the payment of dividends through a variety of market imperfections, such as agency problems (see, for example, Easterbrook, 1984; Gugler, 2003; Jensen, 1986; Jiraporn, Kim, \& Kim, 2011; La Porta, Lopez-DeSilanes, Shleifer, \& Vishny, 2000), information asymmetries (see, for example, M. Baker, Stein, \& Wurgler, 2003; Miller and Rock, 1985) and taxes (see, for example, Amihud \& Murgia, 1997; Bell \& Jenkinson, 2002; Lasfer, 1996; Morck \& Yeung, 2005; Oswald \& Young, 2004; Rau \& Vermaelen, 2002). More recently, other explanations, based on behavioral finance, have been emphasized, such as investor sentiments and market timing (see, among others, M. Baker \& Wurgler, 2004; M. Baker, Wurgler, \& Yuan, 2012).

In view of the constant technological changes that affect the telecommunications sector in particular, it is important to understand the characteristics that most influence the payment of dividends in this sector. The development of the mobile internet and the consequent impact it has on the lives of all of us means telecommunications companies play a fundamental role in the world economy, increasing interest in the literature on the viability of telecommunications as one of the determinants of economic growth (Sridhar \& Sridhar, 2007).

Given the growing interest in the topic, not only for academics, but also for managers, investors, and society in general, this article aims to determine the specific characteristics of the companies under analysis that most contribute to explaining the distribution of dividends in the telecommunications sector, traditionally considered to be one that distributes higher levels of earnings. In addition, we intend to verify the overall significance of these characteristics under the effect of the global financial crisis, which reached its peak with the bankruptcy of Lehman Brothers in 2008.

To achieve this objective, we propose an explanatory model of dividends based on traditional theories and which includes variables of investment, financing, and short-term management, for the period from 2007 to 2016 and, in addition, with the purpose of capturing the differences in a period considered to be a global financial crisis, for the period between 2008 and 2013, following Neves, Fernandes, and Martins (2019).

The estimation of the model, using the generalized method of moments (GMM) for a sample that includes listed telecommunications companies based in the United States, Canada, and Europe, with data on dividends paid in the period under study, shows interesting results. We 
found that there are no significant differences in the specific determinants of dividends in this sector, in stable or crisis periods, corroborating the idea that it is a sector of enormous expansion and potential interest for investors. Companies that pay dividends maintain this behavior, even in periods of sharp global recession.

This article is structured as follows: in the following section, a brief review of the literature on the topic is presented; in Section 3, the data, variables, and methodology are presented; in Section 4, the model is applied and the main results are discussed; finally, in Section 5, the main conclusions, limitations, and suggestions for future research are laid out.

\section{Literature Review and Hypotheses}

The traditional view arising from the thinking of Lintner (1956) tells us that dividend policy is a function of current profits and past dividends, and is decisive for the company's valuation in the market. Miller and Modigliani (1961) argue that the dividends that companies pay do not affect the value of their shares or the profitability of investors, because the higher the dividends, the greater the capital appreciation, and it is irrelevant when choosing a company to invest in whether it distributes dividends or not, if the market works efficiently, and if taxes and transaction costs are excluded.

Since the market does not work efficiently, and there are taxes and transaction costs, the theories to explain dividends are diverse, with the following being possible: the clientele theory, defended by Allen, Bernardo, and Welch (2000), Black and Scholes (1974), and Miller and Modigliani (1961); Bhattacharyya's (1979) "bird in hand" theory; agency theory, by Jensen and Meckling (1976); Bhattacharya's (1979) signaling theory, corroborated by Brickley (1983); the theory of fiscal disadvantages, by Allen and Michaely (2003) and Damoradan (2001); Allen and Michaely's (2003) theory of transaction costs; and Baker and Wurgler's (2004) dividend catering theory. Based on traditional theories of dividends, our paper proposes six specific variables in explaining the dividends distributed per share. For example, Gregoriou, Healy, and Gupta (2015), following literature related to market valuation and expectations of high earnings in high-tech companies (Chiang \& Mensah, 2004; Glaum \& Friedrich, 2006), also opted for financial determinants to explain the volatility of telecommunications companies' share price. The first variable to consider will be investment in fixed assets. Partington and Chenhall (1983) demonstrate that the motivation to pay dividends and the amount paid depends on the investment made and growth potential. The relationship they demonstrate is a negative one in that growth opportunities invalidate all the financial availability that would be used to pay dividends (Faccio, Lang, \& Young, 2001; Gaver \& Gaver, 1993; Smith \& Watts, 1992). Companies with the greatest growth potential tend to retain most of their earnings in order to reduce dependence on more expensive external financing (Alli, Khan, \& Ramirez, 1993; Kania \& Bacon, 2005). Likewise, DeAngelo, DeAngelo, and Stulz (2006), Fama and French (2001), and Jabbouri (2016) observed that companies' propensity to pay dividends was negatively associated with growth opportunities.

On the other hand, if shareholders feel insecure and doubt the company's future results, because of investment projects with a negative net present value (NPV), they will prefer the company to distribute its gains in the form of dividends instead of taking advantage of the possible investment opportunities (La Porta et al., 2000). Also, Denis and Osobov (2008) found that the association between dividends and growth opportunities was not always the same. The authors show that the likelihood that companies will pay dividends was negatively related to growth opportunities in common law countries; however, this relationship was positive in civil law countries.

Given that in the sample used in the present study, the probabilities of future investment were not apparent, but there was variability 
of net investment in fixed assets year on year, our first hypothesis suggests a possible negative relationship between investment and dividends.

H1: The greater the investment in fixed assets, the lower the dividends paid per share.

With regard to the capital structure, several studies show the influence of this variable on dividend policy (H. K. Baker, Powell, \& Veit, 2001). However, the financial literature is not consistent, as there are authors who prove a positive relationship between debt and dividends, while others corroborate the existence of a negative relationship between these variables.

For example, Smith and Watts (1992) verified the existence of a positive relationship between dividend yield and indebtedness. The authors attributed this association to the fact that managers, based on the company's growth opportunities, jointly decide on the dividend and indebtedness policy. Neves (2018) also observed a positive relationship between indebtedness and the payout ratio based on the complementarity between debt and dividends as a control mechanism (Jensen, 1986). On the other hand, Rozeff (1982) points out that companies with high financial leverage tend to have low levels of dividend payments, in order to reduce transaction costs associated with external financing. Also, Jabbouri (2016), Papadopoulos and Charalambidis (2007), and Eije and Megginson (2008) observed a negative relationship between dividends and the debt ratio.

Considering the previous literature, in our second hypothesis, which seeks to relate debt and dividends, we have not defined the sign.

H2a: There is a negative relationship between the level of corporate debt and the dividend per share.

H2b: There is a positive relationship between the level of corporate debt and the dividend per share.
Regarding book value (per share) as a possible determinant of the distribution of dividends, there is not much literature that can be directly quoted, since it is an indicator that is normally used for the investor to understand if the stock is undervalued. For example, Gregoriou et al. (2015) suggest that capital expenditures and book value are significant accounting variables in explaining the volatility of telecommunications companies' share prices. However, as it is one of the most important indicators of company valuation (Kumar, 2015) it is assumed that it will have a positive relationship with the dividend policy, not least because a good part of the equity value is obtained through the net result, which in turn is seen by the classic literature as a determinant of the dividend payments, as shown, for example, by Denis and Osobov (2008), Koch and Sun (2004), Lintner (1956), and Skinner (2008).

H3: The higher the book value per share, the higher the level of dividends paid per share.

According to the free cash flow theory of Jensen (1986), if a company has cash flow not consumed by projects with positive NPV, it is better to return the excess cash to shareholders, in order to maximize their wealth and reduce the possibility of these funds being wasted by managers on projects with negative NPV. This theory therefore predicts that a higher FCF can lead to higher dividend payments to prevent companies suffering from the so-called overinvestment effect. The positive relationship between dividends and free cash flow is supported, for example, by Chaplinsky and Niehaus (1993), DeAngelo et al. (2004), and Holder, Langrehr, and Hexter (1998), who show that overinvesting processes worsen in companies that accumulate high proportions of cash and distribute low dividends. Following the same reasoning, Miguel, Pindado, and La Torre (2005) document the role played by dividends in controlling overinvestment processes in companies with high levels of FCF. 
In fact, several studies show that paying high dividends can be used to decrease agency costs and mitigate information asymmetry problems by reducing discretionary funds (Fairchild, 2010). Following the theory of Jensen (1986), Neves (2018) also found a positive relationship between the FCF and the payout ratio in companies in the euro zone. According to this empirical evidence, the following hypothesis is proposed:

H4: There is a positive relationship between a company's free cash flow and dividends per share.

Working capital is understood as a measure of management efficiency and an excellent measure of liquidity. According to Weiner (2006), the availability of working capital means the company has greater capacity to fulfill its commercial and short-term obligations, as well as remain financially viable.

Therefore, the payment of dividends may be dependent on the management of working capital and current liabilities. We can assume, therefore, that working capital and dividend policy are interlinked because more liquidity means more cash to pay dividends. Liquidity is an important consideration for a company when making its dividend decision, since most dividends are usually paid in cash (Pandey, 2005, as cited by Olang and Grace, 2017). In fact, there are authors such as DeAngelo et al. (2004) and Khang and King (2006) who argue that the dividend policy depends much more on the company's cash / liquidity position than on the income statement (profitability).

Also, Kato, Loewenstein, and Tsay (2002) conclude that changes in the dividend policy are mainly due to changes in the company's liquidity. Based on these arguments, it can be assumed that companies that present adequate amounts of working capital have a good cash position and, therefore, pay higher dividends than companies with inadequate levels of working capital.

H5: There is a positive relationship between a company's working capital and dividends per share.

The distribution of dividends has proved, over time, to be a signal to the market of companies' financial strength.

Lintner (1956) showed that past dividends are an essential factor that influences dividend policy, because companies are reluctant to pay dividends at a level that they cannot sustainably pay in the future. Several researchers have tested Lintner's model in different markets and in different time periods and obtained similar results, where past dividends influence current dividends (Allen, 1992; Pourheydari, 2009; Tse, 2005).

Likewise, Bhattacharya (1979) shows that when a company pays dividends it signals to investors that the company maintains sustainability for the future. Also, according to Brav et al. (2005), stable dividend distribution has to be a priority for managers.

According to the aforementioned literature, the last hypothesis is proposed:

H6: There is a positive relationship between the dividend paid in the previous year and the dividend per share for the current year.

Table 1 presents the expected signs for the explanatory variables of our model in a summarized form. 
Table 1

Summary table of the explanatory variables and expected signs

\begin{tabular}{|c|c|c|c|}
\hline Independent Variables & Model Designation & Theoretical Foundation & Expected Signal \\
\hline Investment & ICF & $\begin{array}{c}\text { Das, S. (2017); } \\
\text { Jabbouri, I. (2016); } \\
\text { DeAngelo et al. (2006); } \\
\text { Partington and Chenhall (1983) }\end{array}$ & Negative (-) \\
\hline & & $\begin{array}{c}\text { Smith and Watts (1992); } \\
\text { Neves (2018); }\end{array}$ & Positive (+) \\
\hline Capital Structure & Leverage & $\begin{array}{c}\text { Papadopoulos and Charalambidis (2007); } \\
\text { Eije and Megginson (2008); } \\
\text { Jabbouri (2016). }\end{array}$ & Negative (-) \\
\hline Book Value & BV & $\begin{array}{c}\text { Lintner (1956); } \\
\text { Koch and Sun (2004); } \\
\text { Denis and Osobov (2008); } \\
\text { Skinner (2008). }\end{array}$ & Positive $(+)$ \\
\hline Free Cash Flow & $\mathrm{FCF}$ & $\begin{array}{l}\text { Holder et al. (1998); } \\
\text { DeAngelo et al. (2004); } \\
\text { Fairchild (2010); } \\
\text { Neves (2018). }\end{array}$ & Positive $(+)$ \\
\hline Working Capital & WC & $\begin{array}{c}\text { Kato et al. (2002); } \\
\text { DeAngelo et al. (2004); } \\
\text { Khang and King (2006). }\end{array}$ & Positive $(+)$ \\
\hline
\end{tabular}

\section{Data, Variables, and Methodology}

\section{I Data}

In order to test the hypotheses identified in the previous section, the data were obtained from the Bloomberg Intelligence website, from the Nasdaq website, and from the reports and accounts presented by the companies that make up the sample. The period selected covers 2007 to 2016, which allows for the impact of the global financial crisis that started in 2008 to be verified. The sample was composed of all telecommunications companies paying dividends and listed at the beginning of 2017 in Europe, the United States, and Canada, which were the regions most affected by the subprime crisis.

The analysis period was subject to the availability of data for all selected companies (see Appendix A), with three companies from the United States (General Communication Inc., Level 3 Communications Inc., and Sprint Corp.) being removed from the sample due to the lack of data on the independent variables for at least 5 consecutive years, a necessary condition to test the absence of a second order correlation in the methodology proposed by Arellano and Bond (1991), Arellano and Bover (1995), and Blundell and Bond (1998). The final sample included 34 companies for the period 2007-2016 (10 years). The base currency used was the euro, and the closing exchange rate for the year was used whenever the values were in the currency of the country of origin. Even after reducing the sample, the study is still able to fulfill its objective and continues to monitor the period of the crisis as well as the years following it.

\subsection{Variables}

\subsection{Dependent}

The dependent variable used is the dividend per share, referred to in the model as Divshares, and includes dividends paid in cash 
to shareholders (including preferred shares). It may include dividends paid to minority interests or paid by subsidiaries, if not disclosed separately.

This variable, dividends per share, was chosen due to the fact that it is an easily observed value that is widely disclosed and easy to interpret, unlike total dividends, due to constant changes in the number of shares (M. Baker \& Wurgler, 2012), mainly influenced by the repurchase of shares, which has become a common practice in companies.

\subsubsection{Independent}

The independent variables used for the dividend model were those that gave rise to the hypotheses presented in the previous section ${ }^{1}$.

The investment variable (ICF) represents the variability of net investments in fixed assets year by year. Das (2017) used a similar variable called CFI.

The capital structure variable used is Leverage, measured as the ratio between total debt and total assets, following Bhagat, Bolton, and Lu (2015), Daskalakis and Psillaki (2008), and Neves, Henriques, and Vilas (2019).

The book value variable represents the relationship between the book value of equity (without preferred shares) of a company and the number of shares outstanding.

Our model also incorporates the free cash flow variable, obtained from the interaction of cash flow with the inverse of investment opportunities. The expression for cash flow is CFit $=$ NIAPDit + DEPit, where NIAPDit means net income after preferred dividends and DEPit represents the book value of depreciation, as according to Neves (2018).

Working capital is given by the difference between total working capital and total short-term liabilities.

Finally, the variable that represents the previous year's dividends is given by the dividend per share with a lag of one period.

Table 2

Variables

\begin{tabular}{|c|c|c|c|}
\hline \multirow[t]{2}{*}{ Investment } & \multicolumn{2}{|c|}{ ICF Ativo Fixo Tangível $(n)-$ Ativo Fixo Tangível $(n-1)$} & \multirow[t]{2}{*}{ Das (2017) } \\
\hline & \multicolumn{2}{|r|}{ Ativo Fixo Tangível $(n-1)$} & \\
\hline \multirow[t]{2}{*}{ Capital Structure } & Leverage & Capital Alheio & \multirow[t]{2}{*}{ Neves et al. (2019) } \\
\hline & & Ativo Total & \\
\hline \multirow[t]{2}{*}{ Book Value } & $\mathrm{BV}$ & Valor Contabilístico do Capital Próprio & \multirow[t]{2}{*}{ Gregoriou et al. (2015) } \\
\hline & & Número de ações em circulação & \\
\hline Free Cash Flow & FCF & Operating Cash Flow - Capital Expenditure & Neves (2018) \\
\hline Working Capital & WC & $\begin{array}{l}\text { Working Capital - } \\
\text { Short-term liabilities }\end{array}$ & Kato et al. (2002) \\
\hline
\end{tabular}

\subsection{Methodology}

Our dividend model was estimated using the panel data methodology. This methodology allows us to solve two fundamental problems: the unobservable heterogeneity (which is due to the nature of the problems addressed possibly biasing the results) and the endogeneity.
In fact, unlike cross-sectional analyses, the panel data methodology allows for individual heterogeneity to be controlled. This point is crucial in our study because the dividend decision is closely related to the specificity of each company (Neves, 2018; Vieira, Neves, \& Dias, 2019). In fact, each company may have a 
different propensity to pay dividends, which can be considered as unobserved heterogeneity.

On the other hand, the panel data methodology allows for the endogeneity to be controlled and corrected, which may arise from the casual relationship that the dependent variable may have with the explanatory variables in our study. For this reason, the model was estimated using instruments, that is, we used all the variables on the right side of the model with $\mathrm{t}-1$ lags for the level equations, as suggested by Blundell and Bond (1998), when deriving the system estimator used in this article.

\section{Model and Results}

\section{I Dynamic model - General Method of Moments (GMM)}

Considering the literature previously presented, below we present the model used:

$$
\begin{aligned}
& \text { Divshares }_{\mathrm{i}, \mathrm{t}}=\beta_{0}+\beta_{1} \mathrm{ICF}_{\mathrm{i}, \mathrm{t}}+\beta_{2} \text { Leverage }_{\mathrm{i}, \mathrm{t}}+\beta_{3} \mathrm{BV}_{\mathrm{i}, \mathrm{t}}+\beta_{4} \mathrm{FCF}_{\mathrm{i}, \mathrm{t}}+\beta_{5} \mathrm{WC}_{\mathrm{i}, \mathrm{t}}+ \\
& \beta_{6} \text { Divshares }_{\mathrm{i}, \mathrm{t}-1}+\varepsilon_{\mathrm{i}, \mathrm{t}}
\end{aligned}
$$

where Divshares ${ }_{i, t}$ represents the dependent variable, dividend per share, ICF is the investment in fixed assets variable, Leverage is the ratio between debt and total assets and measures the company's level of indebtedness, BV represents the book value (per share) variable, FCF is the free cash flow, WC is the working capital, and represents the dividend per share from the previous year.

\section{Results}

\section{I Results of the model for the entire period (between 2007 and 2016)}

In the following tables we present the main results of the model estimation, using a dynamic panel in two phases with level equations and with the dependent variable Divshares $\mathrm{i}_{\mathrm{i}, \mathrm{t}-1}$. Table 3 presents the main descriptive statistics of the model variables.

Table 3

\section{Descriptive Statistics}

\begin{tabular}{lcccc}
\hline & Mean & Standard Deviation & Minimum & Maximum \\
\hline Divshares & 2,024 & 3,972 & 0 & 26,015 \\
ICF & 0,081 & 0,040 & 0,0144 & 0,360 \\
Leverage & 0,687 & 0,199 & 0,147 & 1,356 \\
BV & 15,552 & 21,727 & $-21,576$ & 125,75 \\
FCF & 0,0584 & 0,044 & 0 & 0,396 \\
WC & $-0,006$ & 0,107 & $-0,287$ & 0,52 \\
\hline
\end{tabular}

Table 4 presents the results of the model 1 estimation using the GMM estimation method. 
Table 4

Results of the dynamic model estimation

\begin{tabular}{|c|c|c|c|c|c|}
\hline & Coefficient & Standard Error & $\mathrm{Z}$ & P-Value & \\
\hline Divshares(-1) & 0,2160712 & 0,00153 & 141,18 & 0,0000 & *** \\
\hline Const & $-4,1563$ & 0,0757 & $-54,89$ & 0,0000 & *** \\
\hline ICF & 9,8526 & 0,40486 & 24,34 & 0,0000 & $* * *$ \\
\hline Leverage & 5,0014 & 0,09507 & 52,61 & 0,0000 & $* * *$ \\
\hline BV & 0,08922 & 0,00081 & 110,71 & 0,0000 & *** \\
\hline FCF & 2,0265 & 0,30556 & 6,63 & 0,0000 & $* * *$ \\
\hline WC & $-1,4879$ & 0,04028 & $-36,94$ & 0,0000 & $* * *$ \\
\hline Sargan & & & $28,225(43)$ & 0,96 & \\
\hline Wald & & & $1,04(6)$ & 0,0000 & \\
\hline $\operatorname{AR}(1)$ & & & $-1,291$ & 0,1967 & \\
\hline $\operatorname{AR}(2)$ & & & $-1,0202$ & 0,3076 & \\
\hline
\end{tabular}

Note. The regression is performed using an unbalanced data panel consisting of 34 companies and 340 observations. The variables are those previously defined in the previous section. It should also be noted that: i) ${ }^{*},{ }^{* *}$, and ${ }^{* * *}$ indicate levels of significance at $10 \%, 5 \%$, and $1 \%$, respectively; ii) the Sargan test with a p value greater than $5 \%$ shows that the instruments are valid, with the values in parentheses of the test representing the degrees of freedom; iii) the Wald test has a $\mathrm{p}$ value of less than $5 \%$, which means that the joint significance and the coefficients are distributed asymptotically as $\chi 2$ under a null hypothesis of no significance, with the degrees of freedom in parentheses.

As we can see, all the independent variables used are significant, which shows that they are all important in explaining dividends, although not all have the expected sign. Regarding investment in fixed capital, the sign is positive, contrary to what was predicted in hypothesis 1 and, therefore, the results of authors such as Fama and French (2001), DeAngelo et al. (2006), and Jabbouri (2016). However, this can be justified through the view of Gugler (2003). This author suggested that companies with poor growth prospects find it ideal - presumably in response to pressure from external shareholders - to pay substantial amounts of dividends. Fama and French (2001) showed that companies with good investment opportunities pay substantially less dividends. According to Jensen (1989), debt (Leverage) is positive and significant, which suggests that debt and dividends are complementary agency control mechanisms. Therefore, our evidence supports hypothesis $2 \mathrm{~b}$, according to which higher levels of debt are associated with higher dividend payments, which can be understood as an intention to limit the discretionary power of managers over new funds and, consequently, avoid overinvestment in the company. This result is in line with that obtained by Neves (2018).

Regarding the effect of book value on dividends per share, our results show a positive and significant relationship, as we proposed in hypothesis 3. It should be noted that Gregoriou et al. (2015) suggest that accounting variables, such as book value, are important in explaining the volatility of the share price of telecommunications companies and provide relevant information on value to investors in these companies. So it will be important in dividend decisions.

Consistently with hypothesis 4, the free cash flow level of companies positively affects dividends per share. The results of our estimation show that companies with higher levels of FCF pay more dividends as a way of restricting arbitrary use by fund managers and of thus preventing them from investing in unprofitable projects. The results are consistent and we once again support Jensen's theory (1986), following authors such as Fairchild (2010), Miguel et al. (2005), and Neves (2018). 
With regard to short-term management, the results obtained show that there is a negative and significant relationship between liquidity and dividends distributed, which does not support hypothesis 5 . This result, however, can be justified by the fact that the average is negative, which means that this type of company has little liquidity. If there is no liquidity, the dividends are either paid with net results generated or with more indebtedness so as not to trigger negative noise in the capital markets. In this sense, having more liquidity does not necessarily imply more dividends, since having low levels can be used for day-to-day management.

Finally, our results show, as in the traditional literature on dividends, that the dividend from the previous year positively influences the dividend per share for the current year, which proves hypothesis 6, as well as Lintner's theory (1956), supporting, among others, the results of Allen (1992), Pourheydari (2009), and Tse (2005).

\subsection{Results of the model for the financial crisis period (between 2008 and 2013)}

According to the crisis period identified by Neves et al. (2019), below we present the results for the period between 2008 and 2013.

Table 5

Descriptive Statistics

\begin{tabular}{lcccc}
\hline & Mean & $\begin{array}{c}\text { Standard } \\
\text { Deviation }\end{array}$ & Minimum & Maximum \\
\hline Divshares & 2,0884 & 4,0757 & 0 & 26,0155 \\
ICF & 0,081 & 0,0379 & 0,0224 & 0,2457 \\
Leverage & 0,6805 & 0,2053 & 0,1742 & 1,339 \\
BV & 15,506 & 21,747 & $-21,576$ & 121,45 \\
FCF & 0,0665 & 0,0492 & 0 & 0,396 \\
WC & $-0,0054$ & 0,1063 & $-0,2411$ & 0,5197 \\
\hline
\end{tabular}

Table 6

Results of the dynamic model estimation

\begin{tabular}{|c|c|c|c|c|c|}
\hline & Coefficient & Standard Error & $\mathrm{Z}$ & P-Value & \\
\hline Divshares(-1) & 0,2160712 & 0,00153 & 141,18 & 0,0000 & $* * *$ \\
\hline Const & $-4,1563$ & 0,0757 & $-54,89$ & 0,0000 & $* * *$ \\
\hline ICF & 9,8526 & 0,40486 & 24,34 & 0,0000 & $* * *$ \\
\hline Leverage & 5,0014 & 0,09507 & 52,61 & 0,0000 & $* * *$ \\
\hline BV & 0,08922 & 0,00081 & 110,71 & 0,0000 & $* * *$ \\
\hline FCF & 2,0265 & 0,30556 & 6,63 & 0,0000 & $* * *$ \\
\hline WC & 2,0265 & 0,04028 & $-36,94$ & 0,0000 & $* * *$ \\
\hline Sargan & $-1,4879$ & & $28,225(43)$ & 0,96 & \\
\hline Wald & & & $1,04(6)$ & 0,0000 & \\
\hline AR (1) & & & $-1,291$ & 0,1967 & \\
\hline $\operatorname{AR}(2)$ & & & $-1,0202$ & 0,3076 & \\
\hline
\end{tabular}

The regression is performed using an unbalanced data panel consisting of 34 companies and 340 observations. The variables are those previously defined in the previous section. It should also be noted that: i) ${ }^{*}, * *$, and ${ }^{* * *}$ indicate levels of significance at $10 \%, 5 \%$, and $1 \%$, respectively; ii) the Sargan test with a palue greater than $5 \%$ shows that the instruments are valid, with the values in parentheses of the test representing the degrees of freedom; iii) the Wald test has a $\mathrm{p}$ value of less than $5 \%$, which means that the joint significance and the coefficients are distributed asymptotically as $\chi 2$ under a null hypothesis of no significance, with the degrees of freedom in parentheses.

In Table 6, we can see that the results are very similar to those for the entire period, with the exception of the FCF variable, which is no longer significant, and the liquidity variable, which now has a positive sign. In fact, in a period considered to be a deep crisis, according to the 
definition of bull and bear market periods used by Neves et al. (2019), FCF is no longer relevant in the distribution of dividends, which may suggest that it is retained to increase investments in future periods and continue to satisfy future investors' interests. With regard to working capital, it seems that in the absence of FCF, liquidity and indebtedness will be the ways to satisfy shareholders with dividends. This result is relevant, suggesting that liquidity may be even more interesting for paying dividends when the economic cycle is less favorable.

\section{Conclusion}

Dividend policy has been a hotly debated topic in the financial literature, but despite this it continues to be understood as a puzzle in which it is necessary to add more pieces, and it continues to be an open issue.

Our study contributes to a better understanding of the telecommunications sector and the dividend policy carried out by the managers in this sector, and it can assist in the analyses of investors, other managers, financial analysts, and researchers on the subject.

In fact, our investigation adds companyspecific variables, with the aim of verifying whether they influence the payment of dividends per share and are considered by managers when making these decisions. As far as we know, the relationship between the variables used has not been evaluated in previous studies, either theoretically or empirically. Our results support the idea that managers tend to distribute more dividends when faced with higher levels of debt and free cash flow, thus corroborating Jensen's (1986) theory. Likewise, book value, as well as investment in fixed capital, influence the payment of dividends in telecommunications companies in the markets analyzed, suggesting that when faced with investment scenarios, managers continue to pay dividends, satisfying investors. Finally, our results emphasize, as expected, that the level of dividends is similar in consecutive years, thus avoiding rumors, market scrutiny, and shareholder dissatisfaction.

Regarding the subsample considered in this investigation, in order to understand if there are differences in the determinants of dividends in periods of financial crisis, our results show that only two variables show changes. FCF is no longer significant and working capital, as a measure of liquidity, changes its sign to positive. These results suggest that in the absence of FCF, liquidity and indebtedness will be the ways to satisfy shareholders through the payment of dividends, which suggests that liquidity may be even more interesting for paying dividends when the economic cycle is less favorable.

We can say that the sector studied is one of potential interest for investors since these companies pay dividends even in recessive periods.

This paper could be important for academics, who may find in this article to be another piece in the huge puzzle involving dividends; for managers, in that they can see how decisions related to the trade-off between the origins and investments of funds and efficiency in the use of resources have an impact on the volume of earnings to be distributed; for investors, who can understand what characteristics they must seek when looking for companies that pay more dividends; and for society in general, which can get to know better the characteristics of this important sector of activity.

The main limitation of this study is related to the size of the sample that this sector allows and to the lack of information about the payment of dividends made by means other than cash.

For future research, it would be interesting to jointly analyze companies from other markets and sectors, to integrate institutional, legal, and ownership factors, the distinctive characteristics of civil law and common law countries, and cultural factors, namely those studied by Hofstede (2001).

\section{Nota}

1 It should be noted that all variables were weighted by total assets 


\section{References}

Allen, D. E. (1992). Target payout ratios and dividend policy: British evidence. Managerial Finance, 18(1), 9-21.

Allen, F., Bernardo, A. E., \& Welch, I. (2000). A theory of dividends based on tax clientele. Journal of Finance, 55(6), 2499-2536.

Allen, F., \& Michaely, R. (2003). Payout policy. In G. M. Constantinides, M. Harris, R. M. Stulz (Eds.) Handbook of the Economics of Finance: Corporate Finance (Vol. 1, Part. A, Cap. 7, pp. 337-429). North-Holland: Elsevier.

Alli, K. L., Khan, A. Q., \& Ramirez, G. G. (1993). Determinants of corporate dividend policy: A factorial analysis. Financial Review, 28(4), 523-547.

Amihud, Y., \& Li, K. (2006). The declining information content of dividend announcements and the effect of institutional holdings. Journal of Financial and Quantitative Analysis, 41(3), 637-660.

Amihud, Y., \& Murgia, M. (1997). Dividends, taxes, and signaling: Evidence from Germany. Journal of Finance, 52(1), 397- 408.

Arellano, M., \& Bond, S. (1991). Some tests of specification for panel data: Monte Carlo evidence and an application to employment equations. The Review of Economic Studies, 58(2), 277-297.

Arellano, M., \& Bover, O. (1995). Another look at the instrumental variable estimation of errorcomponents models. Journal of Econometrics, 68(1), 29-51.

Baker, H. K., Powell, G. E., \& Veit, E. T. (2001). Factors influencing dividend policy decisions of Nasdaq firms. Financial Review, 36(3), 19-38.

Baker, M., Stein, J. C., \& Wurgler, J. (2003). When does the market matter? Stock prices and the investment of equity-dependent firms. Quarterly Journal of Economics, 118(3), 969-1006.

Baker, M., \& Wurgler, J. (2004). A catering theory of dividends. Journal of Finance, 59(3), 1125-1165.

Baker, M., Wurgler, J., \& Yuan, Y. (2012). Global, local, and contagious investor sentiment. Journal of Financial Economics, 104(2), 272-287.

Banerjee, S., Gatchev, V. A., \& Spindt, P. A. (2007). Stock market liquidity and firm dividend policy. Journal of Financial and Quantitative Analysis, 42(2), 369-398.

Bell, L., \& Jenkinson, T. (2002). New evidence of the impact of dividend taxation and on the identity of the marginal investor. Journal of Finance, 57(3), 1321-1346.

Bhagat, S., Bolton, B., \& Lu, J. (2015). Size, leverage, and risk-taking of financial institutions. Journal of Banking \& Finance, 59, 520-537

Bhattacharyya, S. (1979). Imperfect information, dividend policy, and "the bird in the hand" fallacy. Bell Journal of Economics, 10(1), 259-270.

Black, F., \& Scholes, M. S. (1974). The effects of dividend yield and dividend policy on common stock prices and returns. Journal of Financial Economics, 1(1), 1-22.

Blundell, R., \& Bond, S. (1998). Initial conditions and moment restrictions in dynamic panel data models. Journal of Econometrics, 87(1), 115-144.

Brav, A., Graham, J. R, Harvey, C. R., \& Michaely, R. (2005). Payout policy in the 21st century. Journal of Financial Economics, 77(3), 483-527.

Brickley, J. (1983). Shareholders wealth, information signaling, and the specially designated dividend: an empirical study. Journal of Financial Economics, 12(2), 187-209. 
Chaplinsky, S., \& Niehaus, G. (1993). Do inside ownership and leverage share common determinants? Quarterly Journal of Business and Economics, 32(4), 61-78.

Chiang, C. C., \& Mensah, Y. M. (2004). The determinants of investor valuation of $R \& D$ expenditure in the software industry. Review of Quantitative Finance and Accounting, 22(4), 293-313.

Damodaran, A. (2001). Corporate finance: Theory and practice (2nd ed.). New York: Willey.

Das, S. (2017). Firm characteristics and dividend policy in India. Transnational Corporations Review, 9(3), 190-200.

Daskalakis, N., \& Psillaki, M. (2008). Do Country or firm factors explain capital structure? Evidence from SMEs in France and Greece. Applied Financial Economics, 18(2), 87-97.

DeAngelo, H., DeAngelo, L., \& Skinner, D. J. (2004). Are dividends disappearing? Dividend concentration and the consolidation of earnings. Journal of financial economics, 72(3), 425-456.

DeAngelo, H., DeAngelo, L., \& Stulz, R. (2006). Dividend policy and the earned/contributed capital mix: A test of the life-cycle theory. Journal of Financial Economics 81, (2), 227-254.

Denis, D., \& Osobov, I. (2008). Why do firms pay dividends? International evidence on the determinants of dividend policy. Journal of Financial Economics, 89(1), 62-82.

Easterbrook, F. H. (1984). Two agency-cost explanations of dividends. American Economic Review, 74(4), 650-660.

Eije, H., von, \& Megginson, W. L. (2008). Dividends and share repurchases in the European Union. Journal of Financial Economics, 89(2), 347-374.
Faccio, M., Lang, L. H. P., \& Young, L. (2001). Dividends and expropriation. American Economic Review, 91(1), 54-78.

Fairchild, R. (2010). Dividend policy, signalling and free cash flow: An integrated approach. Managerial Finance, 36(5), 394-413.

Fama, E. F., \& French, K. R. (2001). Disappearing dividends: Changing firm characteristics or lower propensity to pay. Journal of Financial Economics, 60(1), 3-43.

Gaver, J. J., \& Gaver, K. M. (1993). Additional evidence on the association between the investment opportunity set and corporate financing, dividend, and compensation policies. Journal of Accounting and Economics, 16(1-3), 125-160.

Glaum, M., \& Friedrich, N. (2006). After the "bubble": Valuation of telecommunications companies by financial analysts. Journal of International Financial Management \& Accounting, 17(2), 160-174.

Gregoriou, A., Healy, J., \& Gupta, J. (2015). Determinants of telecommunication stock prices. Journal of Economic Studies, 42(4), 534-548.

Gugler, K. (2003). Corporate governance, dividend payout policy, and the interrelation between dividends, R\&D, and capital investment. Journal of Banking and Finance, 27(7), 1297-1321.

Hofstede, G. (2001). Culture's Consequences: Comparing Values, Behaviors, Institutions, and Organizations Across Nations, 2nd ed., Sage, London.

Holder, M. E., Langrehr, F. W., \& Hexter, J. L. (1998). Dividend policy determinants: An investigation of the Influences of stakeholder theory. Financial Management 27(3), 73-82.

Jabbouri, I. (2016). Determinants of corporate dividend policy in emerging markets: Evidence from MENA stock markets. Research in International Business and Finance, 37, 283-298. 
Jensen, M. C. (1986). Agency costs of free cash flow, corporate finance, and takeovers. American Economic Review, 76(2), 323-329.

Jensen, M. C. (1989). Eclipse of the public corporation. Harvard Business Review, 67(5), 61-74.

Jensen, M. C., \& Meckling, W. H. (1976). Theory of the firm: Managerial behavior, agency costs and ownership structure. Journal of financial economics, 3(4), 305-360.

Jiraporn, P., Kim, J-C., \& Kim, Y. S. (2011). Dividend payouts and corporate governance quality: An empirical investigation. Financial Review, 46(2), 251-279.

Kania, S. L., \& Bacon, D. W. (2005). What factors motivate the corporate dividend decision. ASBBS E-Journal, 1 (1), 97-107.

Kato, H. K., Loewenstein, U., \& Tsay, W. (2002). Dividend policy, cash flow, and investment in Japan. Pacific-Basin Finance Journal, 10(4), 443473.

Khang, K., \& King, T. H. D. (2006). Does dividend policy relate to cross-sectional variation in information asymmetry? Evidence from returns to insider trades. Financial Management, 35(4), 71-94.

Koch, A. S., \& Sun, A. X. (2004). Dividend changes and the persistence of past earnings changes. Journal of Finance, 59(5), 2093-2116.

Kumar, B. R. (2015). Determinants of value creation: An empirical examination from UAE Market. International Journal of Economics and Financial Issues, 5(1), 75-85.

La Porta, R., Lopez-De-Silanes, F., Shleifer, A., \& Vishny, R. (2000). Agency problems and dividend policies around the world. Journal of Finance, 55(1), 1-33.
Lasfer, M. A. (1996). Taxes and dividends: The UK evidence. Journal of Banking and Finance, 20(3), 455-472.

Lintner, J. (1956). Distribution of incomes of corporations among dividends, retained earnings, and taxes. American Economic Review, 46(2), $97-$ 113.

Miguel, A., Pindado, J., \& La Torre, C. de (2005). How do entrenchment and expropriation phenomena affect control mechanisms? Corporate Governance: An International Review 13(4), 505-516.

Miller, M. H., \& Modigliani, F. (1961). Dividend policy, growth and the valuation of shares. Journal of Business, 34(4), 411-433.

Miller, M. H., \& Rock, K. (1985). Dividend policy under asymmetric information. Journal of Finance, 40(4), 1031-1051.

Morck, R., \& Yeung, B. (2005). Dividend taxation and corporate governance. Journal of Economic Perspectives, 19(3), 163-180.

Neves, M. E. D. (2018). Payout and firm's catering. International Journal of Managerial Finance, 14(1), 2-22.

Neves, M. E. D., Fernandes, C. M., \& Martins, P. C. (2019). Are ETFs good vehicles for diversification? New evidence for critical investment periods. Borsa Istanbul Review, 19(2), 149-157.

Neves, M. E. D., Henriques, C., \& Vilas, J. (2019). Financial performance assessment of electricity companies: Evidence from Portugal. Operational Research, 1-49. doi: 10.1007/s12351-019-005041

Olang, M. A., \& Grace, A. M. (2017). Effect of working capital on the dividend pay-out by firms listed at the Nairobi securities exchange, Kenya. International Journal of Finance and Banking Research, 3(2), 13-23. 
Oswald, D., \& Young, S. (2004). What role taxes and regulation? A second look at open market share buyback activity in the UK. Journal of Business Finance \& Accounting, 31(1-2), 257-292.

Papadopoulos, D. L., \& Charalambidis, D. P. (2007). Focus on present status and determinants of dividend payout policy: Athens stock exchange in perspective. Journal of Financial Management \& Analysis, 20(2), 24-37.

Partington, G. H., \& Chenhall R. H. (1983). Dividends, distortion and double taxation. Abacus, 19(1), 3-13.

Pourheydari, O. (2009). A survey of management views on dividend policy in Iranian firms. International Journal of Islamic and Middle Eastern Finance and Management, 2(1), 20-31.

Rau, P. R., \& Vermaelen, T. (2002). Regulation, taxes, and share repurchases in the United Kingdom. Journal of Business, 75(2), 245-282.

Rozeff, M. S. (1982). Growth, beta and agency costs as determinants of dividend payout ratios. Journal of financial Research, 5(3), 249-259.

Smith, C. W. Jr., \& Watts, R. L. (1992). The investment opportunity set and corporate financing, dividend, and compensation policies. Journal of financial Economics, 32(3), 263-292.

Skinner, D. J. (2008). The evolving relation between earnings, dividends, and stock repurchases. Journal of Financial Economics, 87(3), 582-609.

Sridhar, K. S., \& Sridhar, V. (2007). Telecommunications infrastructure and economic growth: Evidence from developing countries. Applied Econometrics and International Development, 7(2), 37-56.

Tse, C-B. (2005). Use dividends to signal or not: an examination of the UK dividend payout patterns. Managerial Finance, 31(4), 12-33.

Vieira, E. S., Neves, M. E., \& Dias, A. G. (2019). Determinants of Portuguese firms' financial performance: Panel data evidence. International Journal of Productivity and Performance Management, 68(7), 1323-1342.

Weiner, E. (2006). The new liquidity paradigm: Focus on working capital. Journal of Financial Economics, 32, $145-160$. 


\section{Appendix}

The total number of companies in the sample (with those withdrawn in grey):

\begin{tabular}{|c|c|}
\hline Company ID & Company \\
\hline 1 & TDC A/S \\
\hline 2 & Tele2 AB \\
\hline 3 & Telecom Italia SpA/Milano \\
\hline 4 & Telefonica SA \\
\hline 5 & Telekom Austria AG \\
\hline 6 & Telenor ASA \\
\hline 7 & Telia Co AB \\
\hline 8 & Vodafone Group PLC \\
\hline 9 & Alaska Communications Systems Group Inc \\
\hline 10 & AT\&T Inc \\
\hline 11 & BCE Inc \\
\hline 12 & CenturyLink Inc \\
\hline 13 & TalkTalk Telecom Group PLC \\
\hline 14 & Cincinnati Bell Inc \\
\hline 15 & Cogent Communications Holdings Inc \\
\hline 16 & Consolidated Communications Holdings Inc \\
\hline 17 & Frontier Communications Corp \\
\hline 18 & General Communication Inc \\
\hline 19 & Level 3 Communications Inc \\
\hline 20 & Rogers Communications Inc \\
\hline 21 & Shenandoah Telecommunications Co \\
\hline 22 & Spok Holdings Inc \\
\hline 23 & Sprint Corp \\
\hline 24 & Telephone \& Data Systems Inc \\
\hline 25 & TELUS Corp \\
\hline 26 & T-Mobile US Inc \\
\hline 27 & United States Cellular Corp \\
\hline 28 & Verizon Communications Inc \\
\hline 29 & Windstream Holdings Inc \\
\hline 30 & BT Group PLC \\
\hline 31 & Deutsche Telekom AG \\
\hline 32 & Elisa OYJ \\
\hline 33 & Iliad SA \\
\hline 34 & Koninklijke KPN NV \\
\hline 35 & Orange SA \\
\hline 36 & Proximus SADP \\
\hline 37 & Swisscom AG \\
\hline
\end{tabular}




\section{Supporting Agencies:}

This work is financed by national funds through the Foundation for Science and Technology (FCT), IP, under the project UID / SOC / 04011/2019.

\section{Authors:}

1. Maria Elisabete Duarte Neves, PhD in Finance at Salamanca University, Salamanca, Spain. Email: mneves@iscac.pt

ORCID

(iD) 0000-0002-6250-1113

2. Maria Manuela Cunha, Master Degree in Financial Analysis at Coimbra Business School|ISCAC, Coimbra Portugal.

Email: maria.cunha@millenniumbcp.pt

ORCID

(iD) 0000-0002-3134-2025

3. João Vilas, Master Degree in Financial Analysis at Coimbra Business School|ISCAC, Coimbra, Portugal. Email: jvilas21@gmail.com

ORCIID

(D) 0000-0002-7503-9212

\section{Contribution of each author}

\begin{tabular}{lccc}
\hline Contribution & Maria Neves & Maria Cunha & Joáo Vilas \\
\hline 1. Definition of research problem & $\sqrt{ }$ & $\sqrt{ }$ & $\sqrt{ }$ \\
2. Development of hypotheses or research questions (empirical studies) & $\sqrt{ }$ & $\sqrt{ }$ & $\sqrt{ }$ \\
3. Development of theoretical propositions (theoretical work) & $\sqrt{ }$ & $\sqrt{ }$ & $\sqrt{ }$ \\
4. Theoretical foundation / Literature review & $\sqrt{ }$ & & \\
5. Definition of methodological procedures & $\sqrt{ }$ & $\sqrt{ }$ \\
6. Data collection & $\sqrt{ }$ & $\sqrt{ }$ & $\sqrt{ }$ \\
7. Statistical analysis & $\sqrt{ }$ & $\sqrt{ }$ \\
8. Analysis and interpretation of data & $\sqrt{ }$ & $\sqrt{ }$ \\
9. Critical revision of the manuscript & $\sqrt{ }$ & $\sqrt{ }$ \\
10. Manuscript writing & & & \\
11. Other (please specify which) & & & \\
\hline
\end{tabular}

